UDC 613.955614 .72

DOI: $10.21668 /$ health.risk/2021.3.05.eng

Research article

\title{
REGULARITIES IN DISEASES OF THE MUSCULOSKELETAL SYSTEM DEVELOPING IN SCHOOLCHILDREN UNDER COMPLEX EXPOSURE TO ENVIRONMENTAL FACTORS AND FACTORS RELATED TO LIFESTYLE
}

\author{
S.L. Valina ${ }^{1}$, I.E. Shtina ${ }^{1}$, O.A. Maklakova ${ }^{1,2}$, O.Yu. Ustinova ${ }^{1,2}$, D.A. Eisfeld ${ }^{1}$ \\ ${ }^{1}$ Federal Scientific Center for Medical and Preventive Health Risk Management Technologies, 82 Monastyrskaya \\ Str., Perm, 614045, Russian Federation \\ ${ }^{2}$ Perm State University, 15 Bukireva Str., Perm, 614990, Russian Federation
}

The present research is vital due to diseases of the musculoskeletal system being widely spread and having great social significance as well as a variety of etiological factors that cause this pathology among schoolchildren. Overall, 339 schoolchildren were examined; they attended secondary schools located on territories with different sanitary-hygienic conditions regarding ambient air. Hygienic, clinical-laboratory and instrumental procedures as well as mathematical data processing were applied to fulfill the research tasks. Average daily consumption of food products was estimated as per "Dairies of a weekly schoolchildren's ration"; specific factors related to lifestyle were estimated via questioning performed with a specifically designed authors' questionnaire. Children who attended a secondary school in a city where metallic construction materials were manufactured had manganese concentrations in their blood that were by 8-9 \% higher than among their counterparts from the reference group; lead concentrations in their blood were by 1.9-2.2 times higher than in the reference group and by up to 1.7 times higher than background levels. Priority factors that produce such negative effects on health as diseases of the musculoskeletal system include the following: school subjects with the same complexity do not interchange with simpler ones in schedules; breaks between classes do not conform to hygienic regulations; food rations are imbalanced as per milk products and eggs; physical training and doing sports are irregular; homework takes longer period of times than before. Average ionized calcium contents in blood of children from the test group were by 9.0-14.0\% lower and hydrocortisone contents were by 1.3-1.5 times higher than in the reference group ( $p=0.0001-0.01)$. Lower mineral density of bone tissues was by 1.6 times more frequent among children from the test group $(p=0.04)$. Diseases of the musculoskeletal system were 4.6-15 times more probable and scoliosis was 8-11 times more probable due to persistent exposure to manganese and lead, violated hygienic principles of education process organization and food rations, and low physical activity of schoolchildren. Changes in bone metabolism, activation of a stress-releasing system, and a decrease in bone mass are basic etiopathogenetic regularities in developing chronic pathology of the musculoskeletal system among schoolchildren associated with exposure to specific environmental factors and factors related to lifestyle.

Key words: diseases of the musculoskeletal system, schoolchildren, environmental factors, education process, nutrition, lifestyle, cause-and-effect regularities.

(C) Valina S.L., Shtina I.E., Maklakova O.A., Ustinova O.Yu., Eisfeld D.A., 2021

Svetlana L. Valina - Candidate of Medical Sciences, Head of the Department for Children and Teenagers Hygiene (e-mail: valina@fcrisk.ru; tel.: +7 (342) 237-27-92; ORCID: https://orcid.org/0000-0003-1719-1598).

Irina E. Shtina - Candidate of Medical Sciences, Head of the Laboratory for Complex Issues of Children's Health with a Clinical Group dealing with Medical and Preventive Health Risk Management Technologies (e-mail: shtina_irina@mail.ru; tel.: +7 (342) 237-27-92; ORCID: http://orcid.org/0000-0002-5017-8232).

Olga A. Maklakova - Doctor of Medical Sciences, Head of the Consulting and Polyclinic Department; Associate professor at the Department for Human Ecology and Life Safety (e-mail: olga_mcl@fcrisk.ru; tel.: +7 (342) 236-80-98; ORCID: http: //orcid.org/0000-0001-9574-9353).

Olga Yu. Ustinova - Doctor of Medical Sciences, Deputy Director responsible for clinical work; Professor at the Department for Human Ecology and Life Safety (e-mail: ustinova@fcrisk.ru; tel.: +7 (342) 236-32-64; ORCID: http://orcid.org/0000-0002-9916-5491).

Darja A. Eisfeld - Candidate of Biological Sciences, Deputy Director responsible for general issues (e-mail: eisfeld@fcrisk.ru; tel.: +7 (342) 236-77-06; ORCID: https://orcid.org/0000-0002-0442-9010). 
Introduction. Children's and teenagers' health is an integral indicator and a criterion showing socioeconomic welfare of the society and a state in general [1]. An important trend in scientific research at the moment is revealing basic tendencies of health disorders among contemporary schoolchildren that occur due to influencing hygienic, biological, and epidemiological factors. Studies on structure of morbidity and regularities in development of morphofunctional disorders as well as chronic diseases help determine priority trends in prevention and healthpreserving activities provided for children [2].

According to latest research data diseases of the musculoskeletal system and connective tissue still hold the leading rank place in the structure of morbidity among schoolchildren [1-4].

According to statistic data, in 2019 the first diagnosed pathogenesis of the musculoskeletal system amounted to $3,107.1$ cases per 100,000 children aged 0-14 (in 2000, 2,904.0 cases); 5,603.0 cases per 100,000 teenagers aged 15-17 (in 2000, 3,636.3 cases) ${ }^{1}$.

Results provided by clinic research indicate that progressing changes in the musculoskeletal system can exert negative impacts on development and functioning of the respiratory, cardiovascular, digestive, nervous, and reproductive system [4].

At present postural disorders and foot flattening are the most widely spread functional disorders of the musculoskeletal system in children and teenagers; scoliosis and flat feet are prevailing chronic diseases [3].

Bone tissue is a dynamic system where interconnected resorption and osteosynthesis cycles go on continuously. Remodeling is especially intense at a time when a child goes to school and it results in the bone system being highly sensitive to adverse effects produced by medical-biological and social-hygienic environmental factors $[5,6]$.

According to domestic researchers, a disease is idiopathic in 45-90\% registered cases of musculoskeletal pathology. Dayer R. and colleagues (2013) made an attempt to systema- tize the existing theories of etiopathogenesis regarding this nosologic category and ranked metabolic disorders in a body among leading causes for the pathology development together with genetic predisposition [7].

Besides, multiple studies established that the most frequent reasons for disorders developing in the musculoskeletal system included low physical activity among children and teenagers and imbalanced food rations influenced by conditions in school as well as hygienic and social ones [4].

Contamination of environmental objects with technogenic metals is the most significant hygienic factor that produces negative effects on bone tissue structure; when such metals penetrate a body in excessive quantities, their long-term cumulation and metabolism lead to disorders in the skeleton mineralization [8].

It is necessary to reveal risk factors that exert negative influence on formation of the musculoskeletal system in schoolchildren and to establish relevant cause-effect regularities since it provides timely diagnostics, prevention, and proper correction of disorders and diseases of the musculoskeletal system.

Our research goal was to establish etiopathogenetic regularities in diseases of the musculoskeletal system in schoolchildren associated with specific exposures to environmental risk factors and factors related to lifestyle.

Data and methods. Overall, 193 schoolchildren attending a secondary school (hereinafter School) were examined; the school was located in a city where there was a production facility manufacturing contraction metal ware. The reference group was made up of 146 schoolchildren who attended a gymnasium (hereinafter Gymnasium) located in an area without any industrial objects. All examined children were divided into several sub-groups as per their grades; the test sub-group 1 and the reference sub-group 1 included $1^{\text {st }}$ grade children (School, 37; Gymnasium, 48); the test sub-group 2 and the reference sub-group 2, $4^{\text {th }}$ grade children (School, 40: Gymnasium, 46); the test sub-group 3 and the

\footnotetext{
${ }^{1}$ The Russian statistical annual, 2020: Statistic data collection. Rosstat. Moscow, 2020, 700 p.
} 
reference sub-group 3, middle-school children (School, 58; Gymnasium, 28); the test sub-group 4 and the reference sub-group 4, senior schoolchildren (School, 58; Gymnasium, 24). The subgroups from the same grades were comparable as per sex and age $(p>0.05)$.

Children to be included into the study didn't have any hereditary diseases of the musculoskeletal system or grave chronic somatic diseases; their parents or legal representatives were asked to give written consent on their participation, and an absence of such consent was a criterion for exclusion.

Air quality inside classrooms as well as ambient air quality on territories where the examined educational establishments were located was hygienically assessed based on data provided by measurements accomplished by experts of the Department for Chemical and Analytical Research Techniques at the Federal Scientific Center for Medical and Preventive Health Risk Management Technologies in March-September 2020. There were three points at which samples were taken: the first one was located outside for taking ambient air samples; the second one was located inside classes where junior schoolchildren studied (junior schoolchildren in each class usually spend all their school day in the same classroom); the third one was located in equipped classrooms and other school premises where middle-school and senior schoolchildren had their lessons. 4 air samples were taken at each point during a day; they were then analyzed, and an average daily concentration of an analyzed chemical was calculated. Manganese and lead were detected in air samples with mass spectrometry in accordance with Methodical guidelines MUK 4.1.3481-17 "Measuring mass concentrations of chemicals in ambient air with mass spectrometry with inductively coupled plasma".

Manganese and lead were quantitatively determined in children's blood with mass spectrometry with inductively coupled plasma on Agilent $7500 c x$ mass spectrometer ("Agilent Technologies Inc.", USA) in accordance with methodical guidelines MUK 4.1.3230-14 $4^{3}$ and MUK 4.1.3161-14 .

A comparative assessment was performed to determine whether an education regime corresponded to requirements fixed in sanitary legislation $^{5}$; it was done based on analyzing school schedules including lessons and breaks.

Data taken from "Dairies of a weekly schoolchildren's ration" were obtained by 24-hour recording of a child' food ration; these data were used to compare food rations consumed by primary, middle, and senior schoolchildren in School and Gymnasium with average daily food rations recommended by Sanitary Rules and Standards SanPiN 2.4.5.2409-08 for children attending secondary educational establishments ${ }^{6}$.

\footnotetext{
${ }^{2}$ MUK 4.1.3481-17. Izmerenie massovykh kontsentratsii khimicheskikh elementov v atmosfernom vozdukhe metodom massspektrometrii s induktivno svyazannoi plazmoi [MUK 4.1.3481-17. Measuring mass concentrations of chemicals in ambient air with mass spectrometry with inductively coupled plasma]. Available at: https://files.stroyinf.ru/Index2/1/4293735/4293735234.htm (June 23, 2021) (in Russian).

${ }^{3}$ MUK 4.1.3230-14. Izmerenie massovykh kontsentratsii khimicheskikh elementov v biosredakh (krov', mocha) metodom mass-spektrometrii s induktivno svyazannoi plazmoi [MUK 4.1.3230-14. Measuring mass concentrations of chemicals in biological media (blood and urine) with mass spectrometry with inductively coupled plasma]. KODEKS: an electronic fund for legal and reference documentation. Available at: https://docs.cntd.ru/document/495856222 (June 23, 2021) (in Russian).

${ }^{4}$ MUK 4.1.3161-14 Izmerenie massovykh kontsentratsii svintsa, kadmiya, mysh'yaka v krovi metodom massspektrometrii s induktivno svyazannoi plazmoi [MUK 4.1.3161-14. Measuring mass concentrations of lead, cadmium, and arsenic in blood mass spectrometry with inductively coupled plasma]. KODEKS: an electronic fund for legal and reference documentation. Available at: https://docs.cntd.ru/document/1200121438 (June 23, 2021) (in Russian).

${ }^{5} \mathrm{SanPiN}$ 2.4.2.2821-10. Sanitarno-epidemiologicheskie trebovaniya k usloviyam i organizatsii obucheniya $\mathrm{v}$ obshcheobrazovatel'nykh uchrezhdeniyakh [Sanitary-epidemiological requirements to the conditions and organization of training in secondary educational establishments]. KODEKS: an electronic fund for legal and reference documentation. Available at: https://docs.cntd.ru/document/902256369 (23.06.2021) (in Russain).

${ }^{6}$ SanPin 2.4.5.2409-08. Sanitarno-epidemiologicheskie trebovaniya k organizatsii pitaniya obuchayushchikhsya v obshcheobrazovatel'nykh uchrezhdeniyakh, uchrezhdeniyakh nachal'nogo i srednego professional'nogo obrazovaniya [SanPiN 2.4.5.2409-08. Sanitary-epidemiological requirements to organizing nutrition for students attending secondary educational establishments and establishments for primary and secondary vocational training]. KODEKS: an electronic fund for legal and reference documentation. Available at: https://docs.cntd.ru/document/902113767 (June 23, 2021) (in Russain).
} 
A social survey was conducted among schoolchildren by asking them to fill in distributed questionnaires; it was done to assess certain factors related to their lifestyle (educational loads beyond basic educational programs, children's and teenagers' physical activity).

Clinical examinations were performed in conformity with the basic ethical standards stipulated in Helsinki Declaration (last edited in 2008). The research program was approved by the Ethical Committee of the Federal Scientific Center for Medical and Preventive Health Risk Management Technologies (the meeting report No. 17 dated February 03, 2020). All the participants were informed about the research goal and techniques; after that they gave their written informed voluntary consent on medical intervention being performed and their personal data being processed.

Spinal column deformities and postural disorders were diagnosed in children and teenagers with computer optical topography (KOMOT) of a human body with "TODP optical no-touch computer topograph for determining spinal column deformities" (Novosibirsk) that provided an opportunity to determine a three-dimensional body shape in the system of absolute coordinates.

Quantitative ultrasound densitometry was applied to detect any disorders of bone strength; it was done with Sunlight Omnisense 7000 device (Sunlight Medical Ltd., Israel). The examination was performed on the distal radius involving assessment of integral Z-score for speed of ultrasound wave (Speed of Sound or $\mathrm{SOS}, \mathrm{m} / \mathrm{sec}$ ). Z-score SOS value ranging from -1 to -2 SD corresponded to the $10 \%$ - percentile. A decrease in bone strength was diagnosed when Z-score SOS value was lower than -1 SD taking into account age and sex in accordance with the reference base stored by a manufacturer in the analyzer software. A fall in speed of sound below $3 \%$-percentile (Z-score was lower than -2 SD) corresponded to the apparent decrease in bone strength.

A biochemical examination was performed regarding calcium-phosphor metabolism. To get a picture of calcium metabolism, contents of its ionized form were determined with EasyLyte
Calcium (Medica Corp., USA) blood electrolyte analyzer.

Adaptive hormone hydrocortisone was detected with BioTek ELx808 (USA) ELISA analyzer.

Morbidity with diseases of the musculoskeletal system was comparatively analyzed based on data taken from "Medical case history of a child attending an educational establishment" (Form No. 026/y-2000) and results of clinical examinations performed by pediatrists and experts on physical therapy.

Data were statistically analyzed with SPSS 10.0 and 16.0 software packages for Windows using correlation and regression analysis. To quantitatively describe correlations between indicators, we calculated odds ratio $(O R)$ and its confidence interval $(C I)$.

Multiple models that showed "factor - response (nosology)" dependence were used to assess a probability of specific responses caused by exposure to factors exceeding hygienic standards. Parameters of a multiple model that reflected "factor - probable response" were estimated with building up a logistic regression model:

$$
p=\frac{1}{1+e^{-\left(b_{0}+\sum_{i} b_{i} x_{i}\right)}},
$$

where $p$ is a probability that a response will deviate from physiological standard;

$x_{i}$ is a level of exposure to a factor; model.

$b_{0}, b_{i}$ are parameters of a mathematical

Differences in the results were considered statistically significant at $p \leq 0.05$.

Results and discussion. Assessment of air quality inside the tested educational establishments revealed that average manganese contents were by 1.6 times higher than the hygienic standard in classrooms for junior schoolchildren in School; manganese and lead contents were by 5.2-8.1 times higher in classrooms School in comparison with Gymnasium $(p<0.05)$ (Table 1).

Contents of these two chemicals were by $1.25-5.25$ times higher in air inside equipped classrooms and other school premises for middle-school children and senior 
Regularities in diseases of the musculoskeletal system developing in schoolchildren under complex exposure...

Table 1

Average chemical concentrations inside classrooms

\begin{tabular}{|c|c|c|c|c|c|}
\hline \multirow{2}{*}{ Chemical } & \multirow{2}{*}{$\begin{array}{c}\text { RfC, } \\
\mathrm{mg} / \mathrm{m}^{3}\end{array}$} & $\begin{array}{c}\text { MPC av.d., } \\
\mathrm{mg} / \mathrm{m}^{3}\end{array}$ & \multicolumn{2}{|c|}{ Concentration, $\mathrm{mg} / \mathrm{m}^{3}$} & \multirow{2}{*}{$p$} \\
\hline \multicolumn{7}{|c|}{ Classrooms for junior schoolchildren } & Gymnasium \\
\hline Manganese & 0.00005 & 0.001 & $0.000078 \pm 0.000016$ & $0.000015 \pm 0.000003$ & $<0.05$ \\
\hline Lead & 0.0005 & 0.0003 & $0.000025 \pm 0.000005$ & $0.0000031 \pm 0.0000007$ & $<0.05$ \\
\hline \multicolumn{7}{|c|}{ Equipped classrooms and other school premises (middle and senior school) } \\
\hline Manganese & 0.00005 & 0.001 & $0.000042 \pm 0.000009$ & $0.000008 \pm 0.000002$ & $<0.05$ \\
\hline Lead & 0.0005 & 0.0003 & $0.000007 \pm 0.000001$ & $0.0000056 \pm 0.0000013$ & $<0.05$ \\
\hline
\end{tabular}

Table 2

Average chemical concentrations in ambient air on the territories where School and Gymnasium were located

\begin{tabular}{|c|c|c|c|c|c|}
\hline \multirow{2}{*}{ Chemical } & \multirow{2}{*}{$\begin{array}{c}\text { RfC, } \\
\mathrm{mg} / \mathrm{m}^{3}\end{array}$} & $\begin{array}{c}\text { MPC av.d., } \\
\mathrm{mg} / \mathrm{m}^{3}\end{array}$ & \multicolumn{2}{|c|}{ Concentration, $\mathrm{mg} / \mathrm{m}^{3}$} & \multirow{2}{*}{ School } \\
\hline Manganese & 0.00005 & 0.001 & $0.000183 \pm 0.000038$ & $0.000039 \pm 0.000008$ & $<0.05$ \\
\hline Lead & 0.0005 & 0.0003 & $0.000020 \pm 0.000004$ & $0.0000065 \pm 0.0000013$ & $<0.05$ \\
\hline
\end{tabular}

schoolchildren in School in comparison with Gymnasium $(p<0.05)$.

Lead was detected in ambient air on the territory where School was located $(0.000020 \pm$ $\pm 0.000004 \mathrm{mg} / \mathrm{m}^{3}$ ) and its concentrations was by 3.1 times higher than in ambient air on the territory where Gymnasium was located (the reference territory) $(p<0.05)$ (Table 2). Manganese contents in ambient air on the territory where School was located were by 3.7 times higher than the reference value and by 4.7 times higher than on the reference territory $(p<0.05)$.

Chemical and analytical examinations revealed that children from the $1^{\text {st }}$ grade in School had 1.9 times higher lead contents in blood than their counterparts from Gymnasium $(0.0213 \pm 0.0036$ against $0.0111 \pm 0.0014$ $\left.\mathrm{mg} / \mathrm{dm}^{3}, p<0.05\right)$. A share of blood samples with elevated lead contents was by 5.5 times higher in the test sub-group 1 than the reference sub-group 1 (72.7 against $13.3 \%, p<0.0001$; $O R=15.77 ; C I=5.75-52.14 ; p<0.0001)$.

Lead contents in blood of children from the $4^{\text {th }}$ grade in School were by 2.2 times higher than the same parameter in blood of their counterparts in Gymnasium $(0.0245 \pm 0.0031$ against $\left.0.0113 \pm 0.0026 \mathrm{mg} / \mathrm{dm}^{3}, p<0.05\right)$ and by 1.7 times higher than the regional background level $(p<0.05)$. Lead contents in blood of children from the test sub-group 2 were ele- vated in $82.7 \%$ cases against $11.1 \%$ cases in the reference sub-group 2 (by 7.4 times higher) $(p<0.0001)$.

Average lead contents in blood of middleschool children in School were also by 1.9 times higher than the same parameter in Gymnasium $(0.0226 \pm 0.0056$ against $0.0118 \pm$ $\left.\pm 0.0019 \mathrm{mg} / \mathrm{dm}^{3}, p<0.05\right)$ and by 1.6 times higher than the regional background level $(p<0.05)$.

Children from the test sub-groups 1,2 and 3 had manganese contents in their blood that were by $8-9 \%$ higher than the same parameters in the reference sub-groups 1,2 , and 3 $\left(0.012 \pm 0.001\right.$ against $0.011 \pm 0.001 \mathrm{mg} / \mathrm{dm}^{3}$, $0.013 \pm 0.002$ against $0.012 \pm 0.001 \mathrm{mg} / \mathrm{dm}^{3}$ and $0.012 \pm 0.001$ against $0.011 \pm 0.002 \mathrm{mg} / \mathrm{dm}^{3}$ accordingly, $p \leq 0.0001-0.01)$. A share of blood samples with elevated manganese contents was by 1.1-2.1 times higher in junior and middle classes in School than in Gymnasium (the $1^{\text {st }}$ grades, 27.3 against $24.4 \%$; middle school, 28.6 against $21.4 \%, p=0.48-0.76$ ), difference were statistically significant in $4^{\text {th }}$ grades (33.3 \% against $15.6 \%, p=0.049$ ).

We established statistically significant relationships between manganese and lead contents in blood and individual doses inhaled with air inside classrooms based on causeeffect relations modeling $\left(R^{2}=0.13-0.66\right.$; $47.32 \leq F \leq 603.60 ; p \leq 0.00001$ ) (Table 3). 
Table 3 peak educational load was detected on Friday

Model parameters for relationships

"A chemical dose inhaled with air inside classrooms - a chemical concentration in blood"

\begin{tabular}{|c|c|c|c|c|c|}
\hline Chemical & $b_{0}$ & $b_{1}$ & $F$ & $p$ & $R^{2}$ \\
\hline Manganese & 0.01079 & 453.20881 & 47.3183 & 0.0000 & 0.13 \\
\hline Lead & 0.01267 & 10107.92284 & 603.6043 & 0.0000 & 0.66 \\
\hline
\end{tabular}

Research results regarding metal contents in blood of children and teenagers who live and study under aerogenic exposure to chemical environmental factors are in line with data provided by several authors who accomplished their research on territories where industrial and energy-producing enterprises were located [9-11].

Educational regimes in School and Gymnasium were assessed to determine whether they conformed to requirements fixed in sanitary legislation. The assessment revealed that the most frequent violation involved absence of interchanges between difficult and easy subjects during a day and a week (item 10.8$)^{5}$. The principle was violated regarding interchanges between subjects that involved different activities; subjects with different ratio of a static and dynamic component; subjects with prevailing loads on the first or second signaling system; all these violations were established in schedules of schoolchildren from all the grades in School. Schedules drawn up for 5 days out of total 5 study days (100\%) in School had the most difficult subjects as the $1^{\text {st }}$ lesson when schoolchildren were just warming up and/or as the $5^{\text {th }}$ or $6^{\text {th }}$ lesson when they were already tired instead of the $2^{\text {nd }}$ or $4^{\text {th }}$ lesson as it was stipulated by hygienic requirements. Similar violations were established for 4 days out of 6 study days in Gymnasium (66.7 \%). Maximum educational loads for middle-school children were determined according to schedules and difficulty of subjects; in School the peak loads were determined on Tuesday (55 scores) and the easiest day was Wednesday (37 scores) instead of Thursday or Friday (item 10.11 violated) and it failed to provide preservation of optimal working capacity during the whole study week. The same item 10.11 and Appendix 3 in SanPiN 2.4.2.2821-10 $10^{5}$ were also violated in schedule of senior schoolchildren in School since Tuesday was the easiest day ( 31 scores) whereas the
(56 scores). When a child has to face intense mental loads at a time his or her working capacity is declining, it leads to depleting energy potential of a body and chronic stress [12].

Emotional stress was proven to influence long-term contraction of neck muscles and shoulder-girdle muscles that resulted in weaker body balance which, in its turn, led to postural disorders [13].

Education process in School involved using SMART Board during IT classes for 45 minutes and this didn't conform to hygienic requirements fixed in item 10.8 of SanPiN 2.4.2.2821-10 where it was stipulated that use of such teaching aids for children in 3-4 ${ }^{\text {th }}$ grades and older should be limited to 30 minutes. SMART Board SBD600 series was used from 5 to 45 minutes during classes in Gymnasium (median value was equal to 10 minutes).

Besides, item 10.12 was violated in School regarding small breaks (5 minutes instead of stipulated 10) and long ones (15 minutes instead of obligatory 20). It failed to provide the $2^{\text {nd }}$ phase in rest that was responsible for recovered "functional potentials" [14].

Violation of standards regarding breaks in education process leads to lower working capacity, growing fatigue, and stress. When educational process is organized without taking into account physiological principles of changes in schoolchildren's working capacities, it results in a necessity to remain in the same forced working posture for a long time and this posture creates significant loads on the musculoskeletal system [4].

Food rations consumed by schoolchildren in the analyzed educational establishments were compared with average daily rations recommended by the SanPiN 2.4.5.2409- $08^{6}$ for children attending secondary educational establishments. This comparison revealed a statistically significant $(p<0.05)$ lower consumption of wheat bread by all analyzed sub-groups (deficiency in School was 61-69 \%; in Gymnasium, 66-88 \%); rye bread (deficiency in School, 98-99 \%; in Gymnasium, 95-100\%); potato (deficiency in School, 60-70 \%; in Gymnasium, 62-76 \%); fresh vegetables (deficiency in School, 85-88 \%; in Gymnasium, 64-89\%); fish (deficiency in School, 84-91 \%; in Gymnasium, 71-88 \%); 
milk (deficiency in School, 65-83 \%; in Gymnasium, 64-95\%); sour milk products (deficiency in School, 54-75 \%; in Gymnasium, 39-97 \%); curds (deficiency in School, 58-74 \%; in Gymnasium, 29-97 \%); butter (deficiency in School, 79-88 \%; in Gymnasium, 55-87 \%); eggs (deficiency in School, 35-61 \%, in Gymnasium, 35-99 \%) (Table 4). Confectionary products were consumed in quantities on average being by 3.1-6.7 times higher than recommended (excess in School was equal to 293-934\%; in Gymnasium, 389-742 \%, $p<0.0001$ ).

Having compared average daily food rations consumed by schoolchildren who attended the two analyzed establishments, we reveled that children from School consumed vegetables and butter in smaller quantities (by 1.6-2.4 times and 1.4-2.2 times accordingly) than children from Gymnasium due to smaller amounts of these products in food rations consumed by junior and senior schoolchildren $(p=0.0001-0.0004)$. Butter was consumed in quantities that were lower than recommended by the standard, by 4.8-8.1 times lower in
School and by 2.2-6.5 times in Gymnasium $(p<0.0001)$. Junior schoolchildren in School consumed curds in quantities that were by 2.4 times lower than recommended $(p<0.0001)$ and by 1.7 times lower than their counterparts in Gymnasium $(p=0.004)$. Schoolchildren consumed $15.8-26.2 \mathrm{~g}$ of eggs daily and it was by $1.5-2.5$ times lower than recommended $(p<0.0001-0.03)$. Average meat consumption was lower than recommended in School (deficiency was equal to 46-61\%) and it was detected for children from all the analyzed grades $(p<0.0001)$ whereas in Gymnasium deviations from recommended rations $(37-49 \%$ deficiency) were statistically significant only in junior and middle school $(p<0.0001-0.02)$. Senior schoolchildren from School consumed poultry in quantities that were by 2.3 times lower than those consumed by their counterparts from Gymnasium (17.5 \pm 22.6 against $39.9 \pm 22.7 \mathrm{~g}, p=0.01)$ and by 3 times lower than recommended $(p<0.0001)$. Actual quantities of macaroni in food rations consumed by junior schoolchildren from School amounted to

Table 4

Average daily food ration for junior, middle, and senior schoolchildren from School and Gymnasium, (g, ml)

\begin{tabular}{|c|c|c|c|c|c|c|c|c|}
\hline \multirow[b]{2}{*}{$\begin{array}{c}\text { Food } \\
\text { products }\end{array}$} & \multirow{2}{*}{\begin{tabular}{|c|} 
Recommended \\
quantity for \\
children aged \\
$7-10(\mathrm{~g}, \mathrm{ml})$ \\
\end{tabular}} & \multicolumn{2}{|c|}{ Junior school } & \multirow{2}{*}{$\begin{array}{c}\text { Recommended } \\
\text { quantity for chil- } \\
\text { dren aged } 11 \text { and } \\
\text { older }(\mathrm{g}, \mathrm{ml}) \\
\end{array}$} & \multicolumn{2}{|c|}{ Middle school } & \multicolumn{2}{|c|}{ Senior school } \\
\hline & & School & $\begin{array}{l}\text { Gymna- } \\
\text { sium }\end{array}$ & & School & $\begin{array}{l}\text { Gymna- } \\
\text { sium }\end{array}$ & School & $\begin{array}{l}\text { Gymna- } \\
\text { sium }\end{array}$ \\
\hline Rye bread & 80 & $1.6 \pm 3.1$ & $3.8 \pm 9.3$ & 120 & $1.2 \pm 3.2$ & $0.0 \pm 0.0$ & $1.6 \pm 4.0$ & $0.0 \pm 0.0$ \\
\hline Wheat bread & 150 & $57.7 \pm 28.4$ & $51.3 \pm 40.2$ & 200 & $61.4 \pm 53.3$ & $50.0 \pm 39.4$ & $63.5 \pm 83.7$ & $23.8 \pm 35.0$ \\
\hline Cereals, beans & 45 & $46.3 \pm 21.0$ & $54.0 \pm 38.3$ & 50 & $38.3 \pm 26.3$ & $45.4 \pm 27.2$ & $43.1 \pm 33.5$ & $58.9 \pm 23.5$ \\
\hline Macaroni & 15 & $32.3 \pm 20.4$ & $20.2 \pm 15.7$ & 20 & $20.6 \pm 11.6$ & $35.7 \pm 24.2$ & $19.8 \pm 18.7$ & $12.6 \pm 13.4$ \\
\hline Potato & 188 & $56.6 \pm 41.3$ & $71.4 \pm 44.1$ & 188 & $75.4 \pm 53.1$ & $63.1 \pm 24.5$ & $68.2 \pm 57.3$ & $44.9 \pm 37.2$ \\
\hline $\begin{array}{l}\text { Fresh vegetables, } \\
\text { greenery }\end{array}$ & 280 & $41.6 \pm 47.6$ & $99.7 \pm 67.9$ & 320 & $37.1 \pm 40.4$ & $34.0 \pm 40.3$ & $47.8 \pm 57.3$ & $76.8 \pm 59.7$ \\
\hline Fresh fruits & & $3.0 \pm 8.0$ & $155.1 \pm 97.7$ & 18 & $145.9 \pm 150.6$ & $49.7 \pm 54.9$ & $107.2 \pm 91.0$ & $48.9 \pm 52.9$ \\
\hline Meat & 70 & $37.6 \pm 28.7$ & $36.0 \pm 22.5$ & 78 & $39.45 \pm 22.0$ & $49.1 \pm 27.7$ & $30.2 \pm 26.2$ & $57.9 \pm 62.9$ \\
\hline Poultry & 35 & $33.8 \pm 32.4$ & $45.8 \pm 33.1$ & 53 & $8.8 \pm 8.6$ & $8.6 \pm 8.6$ & $17.5 \pm 22.6$ & $39.9 \pm 22.7$ \\
\hline Fish & 58 & $9.1 \pm 10.8$ & $16.8 \pm 18.6$ & 77 & $7.3 \pm 10.3$ & $9.1 \pm 5.4$ & $9.4 \pm 16.6$ & $11.6 \pm 13.0$ \\
\hline Sausages & 14.7 & $43.6 \pm 27.9$ & $22.7 \pm 24.0$ & 19.6 & $33.7 \pm 23.8$ & $14.3 \pm 11.3$ & $40.1 \pm 39.6$ & $19.2 \pm 25.0$ \\
\hline Milk & 300 & $106.1 \pm 76.4$ & $108.0 \pm 81.7$ & 300 & $90.8 \pm 110.4$ & $22.9 \pm 51.1$ & $51.5 \pm 39.9$ & $16.0 \pm 23.8$ \\
\hline $\begin{array}{l}\text { Sour milk } \\
\text { products }\end{array}$ & 150 & $62.2 \pm 70.7$ & $91.3 \pm 81.5$ & 180 & $83.2 \pm 68.8$ & $5.6 \pm 12.5$ & $45.0 \pm 55.1$ & $60.0 \pm 73.0$ \\
\hline Curds & 50 & $21.2 \pm 28.1$ & $35.4 \pm 28.9$ & 00 & $16.7 \pm 21.9$ & $1.7 \pm 3.8$ & $15.6 \pm 21.8$ & $12.4 \pm 18.2$ \\
\hline Cheese & 9.8 & $13.2 \pm 14.4$ & $11.7 \pm 10.8$ & 11.8 & $16.7 \pm 18.3$ & $10.3 \pm 4.0$ & $10.7 \pm 13.5$ & $12.5 \pm 12.6$ \\
\hline Cream & 10 & $2.2 \pm 7.1$ & $7.6 \pm 8.7$ & 10 & $3.9 \pm 6.0$ & $10.3 \pm 16.2$ & $2.5 \pm 6.2$ & $8.9 \pm 19.6$ \\
\hline Butter & 30 & $6.3 \pm 5.2$ & $13.6 \pm 7.4$ & 35 & $6.1 \pm 12.3$ & $4.6 \pm 4.4$ & $4.3 \pm 10.8$ & $6.2 \pm 5.3$ \\
\hline Eggs & 40 & \begin{tabular}{|l|}
$26.2 \pm 33.9$ \\
\end{tabular} & $25.9 \pm 16.3$ & 40 & $24.7 \pm 23.6$ & $0.34 \pm 0.35$ & $15.8 \pm 21.5$ & $13.3 \pm 22.2$ \\
\hline $\begin{array}{l}\text { Confectionary } \\
\text { products }\end{array}$ & 10 & $103.4 \pm 52.1$ & $84.2 \pm 48.3$ & 15 & $62.0 \pm 42.0$ & $100.0 \pm 53.4$ & $58.9 \pm 49.7$ & $73.4 \pm 82.1$ \\
\hline
\end{tabular}


$32.3 \pm 20.4 \mathrm{~g}$ a day and it was by 1.6-2.1 times higher than in Gymnasium and quantities recommended by the standard $(p<0.0001-0.01)$.

All examined children from School consumed sausages in excessive quantities, by 1.7-3.0 times higher than recommended, $p<0.0001-0.008)$. Junior and middle-school children from Gymnasium consumed these products in quantities that were by $1.9-2.4$ times higher than recommended ( $p=0.003-0.01$ ).

Children from Gymnasium faced much greater deficiency of wheat bread due to a decrease in actual quantities of this product in rations consumed by senior schoolchildren $(23.8 \pm 35.0$ against $63.5 \pm 83.7 \mathrm{~g}$ in School, $p=0.05$ ); deficiency of milk occurred due to its lower quantities in food rations consumed by middle and senior schoolchildren $(22.9 \pm 51.1$ against $90.8 \pm 110.4 \mathrm{ml}$ in School and $16.0 \pm$ \pm 23.8 against $51.5 \pm 39.9 \mathrm{ml}$ in School accordingly, $p=0.003-0.05)$. We also detected that middle-school children from Gymnasium consumed sour milk products in extremely low quantities $(5.6 \pm 12.5$ against recommended $180.0 \mathrm{ml}, p<0.0001)$ and it was by 14.9 times lower than in School $(p=0.0001)$.

All these data indicate there is an authentic 2.4-3.8-time decrease $(p<0.0001)$ in consumption of curds by schoolchildren although this product is a source of calcium that is the most easily assimilated by a body. Butter and egg yolk are basic sources of vitamin D that plays a significant role in bone calcification; yet, these products were also consumed in quantities by 4.8-8.1 and 1.5-2.5 times lower than physiological needs accordingly ( $p<0.0001-0.03$ ).

Questioning revealed that most schoolchildren $(79.5 \%$ in School and $98.9 \%$ in Gymnasium) had some additional education beyond school studies; $75 \%$ schoolchildren from School and $97.1 \%$ schoolchildren from Gymnasium spent 15-60 minutes on doing additional homework $(p<0.0001)$. An amount of time spent on doing homework related to additional education grew by $2.0-8.0$ times for $25 \%$ schoolchildren from School (120 minutes and more) whereas a share of schoolchildren from Gymnasium who spent more than 2 hours a day doing their homework was only $2.9 \%(p<0.0001)$. An increase in amount of time spent on doing homework raises "physiological costs" of education.

Hypodynamia is another behavioral aspect that exerts negative influence on the musculoskeletal system. Physical activity is known to improve blood supply and to activate osteoblast functioning, protein synthesis, calcification, and bone tissue metabolism $[15,16]$.

$60.5 \%$ schoolchildren from Gymnasium were quite committed to doing sports since they did physical exercises or sport from 4 to 7 times a week whereas most schoolchildren from School $(76.0 \%)$ attended sports clubs or did physical exercises less than 3 times a week. Only $2.8 \%$ schoolchildren in School had physical activity every day and it was by 4.7 times lower than in Gymnasium (13.2 \%). Differences detected in this variable ("How regularly does a child do sport or physical exercises?") were statistically significant (Mann - Whitney test, $p<0.0001$; Cramer's V correlation coefficient $=$ 0.377 , an average correlation, $p<0.0001$ ).

We detected statistically significant differences in the variable "How many hours a week does a child spend on average on doing sports or exercises?" between School and Gymnasium (Mann - Whitney test, $p<0.0001$; Cramer's V correlation coefficient $=0.306$, an average correlation, $p=0.002$ ). A number of schoolchildren from School who spent 9 hours a week on doing sports or exercises was by 4.6 times lower than in Gymnasium (2.9 \% against $13.3 \%$ ). $10.1 \%$ schoolchildren from School spent 6-8 hours on doing sport and it was by 2.6 times lower than in Gymnasium $(26.7 \%)$. One third of schoolchildren from School did sports for not more than 2 hours a week (31.9\% against $17.8 \%$ in Gymnasium) and more than a half spent on it not more than 3-5 hours a week (55.1\% against $42.2 \%)$ in Gymnasium.

Therefore, physical activities of most school children who participated in the research didn't conform to standards fixed by the World Health Organization that recommends children older than 5 to spend not less than 60 minutes on sport every day and to do power exercises not less than 3 times a week ${ }^{7}$.

\footnotetext{
${ }^{7}$ Adolescent and young adult health. WHO, 2021. Available at: https://www.who.int/news-room/fact-sheets/detail/ adolescents-health-risks-and-solutions (August 18, 2021).
} 
We assessed topographic parameters that characterized a body posture in the frontal plane to reveal that in School only $2.7 \%$ children in the $1^{\text {st }}$ grade had scoliosis but the number grew by the end of the junior school ( $4^{\text {th }}$ grade $)$ and in senior school since $42.9 \%$ and $41.7 \%$ children accordingly had this pathology $(p<0.0001)$. There was a 27-time growth in probability of scoliosis among schoolchildren by end of the middle school $(O R=27.05 ; C I=3.37-217.22$; $p<0.0001$ ), and almost a 26-time growth by the end of the senior school $(O R=25.78$; $C I=3.30-201.10 ; p<0.0001)$. In Gymnasium, a probability that scoliosis would occur grew by 8.5 times in senior school $(O R=8.52$; $C I=2.74-26.48 ; p<0.01)$. When analyzing postural disorders in the sagittal projection, we revealed that by the end of junior school "sway back" was detected only in children from School in $14.3 \%$ cases (against $0.0 \%$ in Gymnasium, $p=0.008$ ).

Quantitative ultrasound examination of bone strength established that a share of schoolchildren from School who had lower bone mineral density (BMD) (Z-score was lower than -1 standard deviation (SD)) was by 1.6 times higher than the same value in Gymnasium (60.0 \% against $36.4 \%, p=0.04)$.

A share of schoolchildren in $4^{\text {th }}$ grade and in middle grades in School who had apparent decrease in bone strength (Z-score was lower than -2 SD) amounted to $21.4 \%$ and $15.0 \%$ accordingly and it was by $1.5-1.6$ times higher than in Gymnasium (14.3 and $9.1 \%$ ) but differences were not statistically significant $(p=0.4)$. We should note that such a disorder requires additional profound examination with $\mathrm{X}$-ray densitometry.
Laboratory tests aimed at examining mineral metabolism established that average contents of ionized calcium in blood of children from the test sub-group No. 1, No. 2, No. 3 and No. 4 were by $9.0-14.0 \%$ lower than in blood of their counterparts from the reference sub-group No. 1, No. 2, No. 3 and No. 4 $(p=0.0001-0.001)$ (Table 5). It is well-known that even a trend towards a decrease in this microelement contents in a body results in calcium being released into blood flow from bones to make up for temporary deficiency [2].

Phosphor contents in blood of $4^{\text {th }}$ grade children and middle-school children were within physiological range both in School and Gymnasium $(p>0.05)$ and there were no statistically significant differences between test and reference sub-groups $(1.61 \pm 0.07$ in the test sub-group No. 2 against $1.6 \pm 0.12 \mathrm{mmol} / \mathrm{dm}^{3}$ in the reference sub-group No. $2, p=0.64$ and $1.55 \pm 0.12$ in the test sub-group No. 3 against $1.58 \pm 0.08 \mathrm{mmol} / \mathrm{dm}^{3}$ in the reference subgroup No. 3, $p=0.23$ ). Contents of this microelement were also within physiological ranges in $1^{\text {st }}$ grade children and senior schoolchildren but differences were multidirectional $(1.58 \pm$ \pm 0.06 against $1.62 \pm 0.07 \mathrm{mmol} / \mathrm{dm}^{3}$ in the test and reference sub-groups No. 1 accordingly, $p=0.007 ;$ and $1.41 \pm 0.08$ against $1.30 \pm 0.06$ $\mathrm{mmol} / \mathrm{dm}^{3}$ in the test and reference sub-groups No. 4 accordingly, $p<0.0001)$.

Average hydrocortisone contents didn't exceed reference levels in blood of children from School but were higher than the same parameter in their counterparts form reference sub-groups: in $1^{\text {st }}$ grade, by 1.4 times higher; $4^{\text {th }}$ grade, by 1.3 times higher; in middle school, by 1.5 times higher $(p=0.001-0.01)$ (Table 5).

Table 5

Calcium and hydrocortisone contents in blood of children from the $1^{\text {st }}$ grade, $4^{\text {th }}$ grade, middle school and senior school in School and Gymnasium

\begin{tabular}{|c|c|c|c|c|c|}
\hline \multirow{2}{*}{ Grade } & \multirow{2}{*}{ Sub-group } & \multicolumn{2}{|c|}{ Ionized calcium } & \multicolumn{2}{|c|}{ Hydrocortisone } \\
\hline & & $\mathrm{mmol} / \mathrm{dm}^{3}$ & $p$ & $\mathrm{nmol} / \mathrm{cm}^{3}$ & $p$ \\
\hline \multirow{2}{*}{$1^{\text {st }}$ grade } & Test sub-group No. 1 & $1.12 \pm 0.02$ & \multirow{2}{*}{0.001} & $295.22 \pm 40.59$ & \multirow{2}{*}{0.001} \\
\hline & Reference sub-group No. 1 & $1.26 \pm 0.01$ & & $207.02 \pm 22.24$ & \\
\hline \multirow{2}{*}{$4^{\text {th }}$ grade } & Test sub-group No. 2 & $1.07 \pm 0.01$ & \multirow{2}{*}{0.001} & $272.45 \pm 40.78$ & \multirow{2}{*}{0.01} \\
\hline & Reference sub-group No. 2 & $1.22 \pm 0.01$ & & $205.95 \pm 22.98$ & \\
\hline \multirow{2}{*}{ Middle school } & Test sub-group No. 3 & $1.11 \pm 0.011$ & \multirow{2}{*}{0.001} & $301.49 \pm 34.86$ & \multirow{2}{*}{0.01} \\
\hline & Reference sub-group No. 3 & $1.22 \pm 0.02$ & & $199.08 \pm 21.85$ & \\
\hline \multirow{2}{*}{ Senior school } & Test sub-group No. 4 & $1.12 \pm 0.01$ & \multirow{2}{*}{0.0001} & $281.22 \pm 32.59$ & \multirow{2}{*}{0.01} \\
\hline & Reference sub-group No. 4 & $1.27 \pm 0.01$ & & $367.74 \pm 48.72$ & \\
\hline
\end{tabular}


Somatic state was comparatively assessed based on profound medical examinations and data taken from "Medical case history of a child attending an educational establishment" (Form No. 026/y-2000). The assessment revealed that diseases of the musculoskeletal system and connective tissue constantly held the $1^{\text {st }}$ rank place in the structure of morbidity among $4^{\text {th }}$ grade children as well as middle and senior school children. These results are in line with data provided by foreign and domestic researchers [2, 3, 16-21].

In School, prevalence of diseases of the musculoskeletal system and connective tissue was by 1.5 times higher among middle-school children and by 1.6 times higher among senior schoolchildren than among $1^{\text {st }}$ grade children (86.9 against $58.8 \%, p=0.003$ and 96.4 against $58.8 \%, p=0.0001)$. In Gymnasium the difference was $1.15-1.2$ times (100.0 against $83.3 \%$, $p=0.02$ and 95.8 against $83.3 \%, p=0.13$ ). There was a 4.6-times growth in probability of diseases of the musculoskeletal system and connective tissue for middle-school children against $1^{\text {st }}$ grade children in School $(O R=4.60$; $C I=1.61-13.12 ; p=0.007)$; this probability grew by 15 times for senior schoolchildren $(O R=15.14 ; C I=3.60-63.60 ; p<0.001)$.

We established an authentic correlation between elevated morbidity with diseases of the musculoskeletal system and connective tissue and elevated manganese and lead contents in blood $\left(0.14 \leq R^{2} \leq 0.58 ; 45.61 \leq F \leq 403.77\right.$; $p \leq 0.0001)$, shorter small breaks between lessons $\left(R^{2}=0.84 ; F=1,838.01 ; p \leq 0.0001\right)$, insufficient consumption of curds, eggs, and butter $\left(0.17 \leq R^{2} \leq 0.86 ; 25.84 \leq F \leq 765.14\right.$; $p \leq 0.0001$ ), more time spent on doing homework due to additional education, and less regular sports and physical exercises $\left(R^{2}=0.46\right.$; $90.56 \leq F \leq 249.76$; $p \leq 0.0001$ ).

Other deforming dorsopathies or postural disorders were diagnosed by 1.7 times authentically more frequently among senior schoolchildren in School than among their counterparts in Gymnasium (56.4 against 33.4\%, $p=0.06$ ).

We established an authentic correlation between elevated morbidity with deforming dorsopathy and improper interchange between easy and difficult subjects during a day/week
$\left(R^{2}=0.44 ; F=269.96 ; p \leq 0.0001\right)$ and elevated manganese and lead contents in blood $\left(0.32 \leq R^{2} \leq 0.64 ; 70.03 \leq F \leq 555.97\right.$; $p \leq 0.0001)$ since these two elements compete with calcium in bone tissue and disrupt biosynthesis and mineralization.

Morbidity was also analyzed in age dynamics; the analysis revealed that in School acquired deformities of limbs (flat foot [pesplanus] acquired) were by 1.4 times more frequently detected among senior schoolchildren than among $1^{\text {st }}$ grade children (60 against $41.2 \%, p=0.07)$ whereas a share of school children with this pathology was stable in Gymnasium and amounted to 72.9-79.2 \%.

There was also an authentic correlation between elevated morbidity with acquired deformities of limbs and elevated lead contents in blood $\left(R^{2}=0.42 ; F=177.57 ; p \leq 0.0001\right)$, improper interchange between easy and difficult subjects during a day/week, a longer period of using an interactive whiteboard $\left(0.77 \leq R^{2} \leq 0.86\right.$; $1,112.63 \leq F \leq 2,144.36 ; p \leq 0.0001)$, and time spent on doing homework assigned due to additional training $\left(R^{2}=0.23 ; F=24.20 ; p \leq 0.0001\right)$.

Osteoporosis without pathological fractures was not diagnosed in $1^{\text {st }}$ grade children in School; still, it was detected in $10 \%$ of $4^{\text {th }}$ grade children $(p=0.05)$ and $18.9 \%$ of middle-school children $(p=0.01)$. In Gymnasium a share of children who had osteoporosis went down from $6.3 \%$ in junior school to $3.6 \%$ in middle school $(p=0.60)$. Therefore, this pathology was diagnosed by 5.2 times more frequently in middle-school children in School against their counterparts in Gymnasium (18.9 against $3.6 \%, p=0.05)$.

Scoliosis, being one of the most widely spread chronic diseases of the musculoskeletal system, was by 5.1 times more frequently detected among $4^{\text {th }}$ grade children in School than among $1^{\text {st }}$ grade ones (15 against $2.9 \%$, $p=0.07)$. A share of middle-school children who had scoliosis was by 6.5 times higher than among $1^{\text {st }}$ grade children and amounted to $18.9 \%$ (against $2.9 \%, p=0.03$ ). A number of senior schoolchildren in School who had scoliosis grew by 8.7 times against $1^{\text {st }}$ grade children (25.5 against $2.9 \%, p=0.01$ ). A probability of scoliosis grew by almost 8 times for middleschool children in School against $1^{\text {st }}$ grade 
children $(O R=7.67 ; C I=0.94-62.99 ; p=0.06)$ and by 11 times for senior schoolchildren $(O R=11.27 ; C I=1.41-90.19 ; p<0.001)$.

We detected an authentic correlation between morbidity with scoliosis and elevated manganese and lead contents in blood $\left(0.10 \leq R^{2} \leq\right.$ $\leq 0.62 ; 33.92 \leq F \leq 261.42 ; p \leq 0.0001)$, improper interchange between easy and difficult subjects during a day/week and distribution of difficult subjects during a day, a longer period of using an interactive whiteboard, shorter small breaks between lessons $\left(0.19 \leq R^{2} \leq 0.88\right.$; $78.83 \leq F \leq 2,605.12 ; p \leq 0.0001)$, insufficient consumption of butter $\left(R^{2}=0.23 ; F=35.15\right.$; $p \leq 0.0001)$, more time spent on doing homework due to additional education $\left(R^{2}=0.43 ; F=\right.$ $43.91 ; p \leq 0.0001)$, less regular sports and physical exercises $\left(R^{2}=0.04 ; F=12.90 ; p=0.002\right)$.

Cause-effect regularities of scoliosis occurrence and relevant laboratory and instrument indicators were established based on analyzing research data, assessing cause-effect relations, and performing step-by-step modeling. These regularities and indicators characterize development of negative effects that occur due to exposure to adverse priority chemical factors in the environment, contemporary education process, eating habits and lifestyle.

Given long-term aerogenic exposure to technogenic chemicals, and adverse factors related to education process and lifestyle, ionized calcium contents in blood is a laboratory indicator that can be used to assess a probability of scoliosis $\left(R^{2}=0.35 ; F=42.30 ; p \leq 0.0001\right)$. These contents are related to effects produced by lead $(r=-0.41$; $p \leq 0.0001$ ) that competes with calcium in bone tissue thus leading to demineralization.

Correlation analysis revealed a correlation between insufficient consumption of curds, a significant source of calcium in food, and contents of this micronutrient in its ionized form in blood $(r=0.17 ; p=0.04)$. Negative trends in eating habits of contemporary Russian schoolchildren, including insufficient milk and milk products consumption, are confirmed by multiple epidemiological researches accomplished by Rospotrebnadzor experts and experts in public healthcare [3].

There are different opinions by researchers on deviations in children's and teenagers' biochemical parameters and their relations with postural disorders. Our research results are in line with data provided by authors who point out negative calcium balance in case there is small orthopedic pathology [22].

There was a correlation between less regular sports and physical exercises $(r=0.22$; $p=0.005)$ as well as shorter small breaks between lessons $(r=-0.57 ; p \leq 0.0001)$ and ionized calcium contents in blood. Our data confirm other researchers' opinions on calcium homeostasis being supported not only by sufficient quantities of calcium, phosphor, and vitamin D, but also proper mineralization of the skeleton that depends on how physically active a person is [15, 23].

Dependence between greater probability of scoliosis and growing hydrocortisone contents in blood $\left(R^{2}=0.18 ; F=66.72 ; p \leq 0.0001\right)$ detected in our research confirms a hypothesis on impacts exerted by chronic stress on changes in bone tissue [6].

Elevated glucocorticoid contents produce negative effects on remodeling of bone tissue and its quality due to a decrease in calcium absorption from the gastrointestinal tract and resorption in kidney tubules [24]. Stressreleasing system activates due to negative factors related to contemporary education process and lifestyle such as shorter small breaks between lessons $(r=0.30 ; p \leq 0.0001)$ and less regular sports and physical exercises $(r=-0.13$; $p=0.03$ ). Research by P.N. Samikulin and colleagues revealed a role played by muscle work in reducing elevated hydrocortisone contents in young males with different levels of training [25].

Bone strength being lower than -1 SD as per Z-score SOS value is another regularity in scoliosis occurrence associated with negative factors related to lifestyle and eating habits $\left(R^{2}=0.39 ; F=56.95 ; p \leq 0.0001\right)$ such as insufficient consumption of curds and $\left(R^{2}=0.25\right.$; $F=35.96 ; p \leq 0.0001)$ and low commitment to doing sports $\left(R^{2}=0.24 ; F=88.79 ; p \leq 0.0001\right)$. A relation between mineral bone density and idiopathic scoliosis was first revealed by F.R. Burner and colleagues in 1982. As per data provided by V.T. Verkhoturova, changes in bone tissues in children and teenagers with scoliosis are caused by disorders in bone tissue micro-architectonics, 
osteosynthetic cells being less active, and changes in the skeleton configuration [26].

The multiple model for "factor - probable response" dependence revealed the following contributions by negative into scoliosis occurrence: $25.8 \%$, factors related to education process; $30.9 \%$, factors related to lifestyle; $20.3 \%$, chemical environmental factors; $23.0 \%$, factors related to eating habits.

Conclusion. Therefore, a probability that diseases of the musculoskeletal system would develop grows by 4.6 times for middle-school children and by 15.0 times for senior school children from the test sub-groups and probability of scoliosis grows by 8.0 and 11.0 times accordingly due to several adverse factors. These factors include persistent exposure to metals resulting in lead concentrations in blood being 0.018-0.028 $\mathrm{mg} / \mathrm{dm}^{3}$ (by 1.9-2.2 times higher than in reference sub-groups and up to 1.6-1.7 times higher than regional background levels) as well as manganese contents being equal to $0.011-0.015$ $\mathrm{mg} / \mathrm{dm}^{3}$ (by $8.0-9.0 \%$ higher than in reference sub-groups); educational process not conforming to requirements fixed inn sanitary legislation; imbalanced food rations; low physical activity.

Cause-effect regularities of scoliosis associated with exposure to adverse environmental factors, contemporary education process, eating habits, and lifestyle include changes in cellular metabolism (ionized calcium) caused by effects produced by lead, less regular sports and physical exercises, shorter small breaks between lessons, and insufficient consumption of curds $(-0.57 \leq r \leq 0.22 ; 0.0001 \leq p \leq 0.04)$; activation of stress-releasing system (hydrocortisone) caused by shorter small breaks between lessons and low commitment to doing sports $(-0.13 \leq r \leq 0.30 ; 0.0001 \leq p \leq 0.03)$; osteopenic syndrome (Z-score) caused by less regular sports and physical exercises and insufficient consumption of curds $\left(-0.25 \leq R^{2} \leq\right.$ $\leq 0.24 ; 88.79 \leq F \leq 35.96 ; p \leq 0.0001)$.

Funding. The research was not granted any sponsor support.

Conflict of interests. The authors declare there is no any conflict of interests.

\section{References}

1. Bantyeva M.N., Manoshkina E.M., Sokolovskaja T.A., Matveev E.N. Trends in incidence and dynamics of chronic pathology in children aged 0-14 in the Russian Federation. Sotsial'nye aspekty zdorov'ya naseleniya, 2019, vol. 65, no. 5, pp. 10. DOI: 10.21045/2071-5021-2019-65-5-10 (in Russian).

2. Mansurova G.Sh., Maltsev S.V., Ryabchikov I.V. Features of formation of the musculoskeletal system in schoolchildren: diseases, causes and possible ways of correction. Prakticheskaya meditsina, 2019, vol. 17, no. 5, pp. 51-55. DOI: 10.32000/2072-1757-2019-5-51-55 (in Russian).

3. Volkova L.Yu. Alimentary factors of bone tissue development in children and adolescents. Preventive measures against potential disorders. Voprosy sovremennoi pediatrii, 2015, vol. 14, no. 1, pp. 124-131 (in Russian).

4. Antonova A.A., Yamanova G.A., Serdyukov V.G., Magomedova M.R. Dynamics of locomotor apparatus state in children and adolescents. Mezhdunarodnyi nauchno-issledovatel'skii zhurnal, 2020, vol. 97, no. 7 (part 2), pp. 53-56. DOI: https://doi.org/10.23670/IRJ.2020.97.7.044 (in Russian).

5. Zyatitskaya A.L. Problem of diagnostics of deterioration in bone strength in children. Byulleten' sibirskoi meditsiny, 2009, vol. 8, no. 2, pp. 76-84 (in Russian).

6. Tazhibaeva D.S., Kabdualieva N.B., Baybakova M.K., Beglarova G.E., Zaripova L.N. The influence of chronic psychosocial stress on bone tissue in medical students. Vestnik Kazakhskogo natsional'nogo meditsinskogo universiteta, 2013, vol. 5, no. 1, pp. 233-236 (in Russian).

7. Kulikov A.G., Zaytseva T.N., Pyzhevskaya O.P., Ivanova E.R. Scoliosis in children: new approaches to the solution of important medical and social problems. Mediko-sotsial'naya ekspertiza i reabilitatsiya, 2016, vol. 19, no. 4, pp. 178-181. DOI: 10.18821/1560-9537-2016-19-4-178-181(in Russian).

8. Onishchenko G.G., Zaitseva N.V., Zemlyanova M.A. Identification of health effects caused by environmental chemical exposure. In: G.G. Onishchenko ed. Perm', Knizhnyi format, 2011, 532 p. (in Russian).

9. Rafikova Yu.S., Semenova I.N., Suyundukov Ya.T., Khasanova R.F., Biktimerova G.Ya., Rafikov S.Sh. Regional peculiarities of metal concentration in blood serum among adolescents of the mining region. Meditsina truda i ekologiya cheloveka, 2017, vol. 10, no. 2, pp. 34-37 (in Russian).

10. Dos Santos N.R., Rodrigues J.L.G., Bandeira M.J., dos S. Anjos A.L., Araújo C.F.S., Adan L.F.F., Menezes-Filho J.A. Manganese exposure and association with hormone imbalance in children living near a ferro-manganese alloy plant. Environ. Res., 2019, vol. 172, pp. 166-174. DOI: 10.1016/j.envres.2019.02.021 
Regularities in diseases of the musculoskeletal system developing in schoolchildren under complex exposure...

11. Menezes-Filho J.A., Carvalho C.F., Rodrigues J.L.G., Araújo C.F.S., dos Santos N.R., Lima C.S., Bandeira M.J., de S. Marques B.L. [et al.]. Environmental Co-Exposure to Lead and Manganese and Intellectual Deficit in School-Aged Children. Int. J. Environ. Res. Public Health, 2018, vol. 15, no. 11, pp. 2418. DOI: $10.3390 /$ ijerph15112418

12. Sadvakasova N.A. Problema umstvennoi rabotosposobnosti u detei [The problem of mental performance in children]. Nauchnoe obozrenie. Fundamental'nye i prikladnye issledovaniya, 2018, no. 3. Available at: https://scientificreview.ru/ru/article/view?id=38 (14.09.2021) (in Russian).

13. Zhulev E.N., Velmakina I.V., Tyurina K.S. Influence of the psychoemotional voltage level on clinical manifestations of muscular-joint dysfunction of the lumino-lower-male joint in young persons. Sovremennye problem nauki i obrazovaniya, 2018, no. 1, pp. 20. Available at: http://science-education.ru/ru/article/view?id=27360 (23.06.2021) (in Russian).

14. Karkashadze G.A., Namazova-Baranova L.S., Zakharova I.N., Makarova S.G., Maslova O.I. Syndrome of high academic loads in school-aged children and adolescents. Pediatricheskaya farmakologiya, 2017, vol. 14, no. 1, pp. 7-23. DOI: 10.15690/pf.v14i1.1697 (in Russian).

15. Mirskaya N.B. Risk factors negatively affecting on the formation of musculoskeletal system in children and adolescents in the present conditions. Gigiena i sanitariya, 2013, vol. 92, no. 1, pp. 65-71 (in Russian).

16. De Assis S.J.C., Sanchis G.J.B., de Souza C.G., Roncalli A.G. Influence of physical activity and postural habits in schoolchildren with scoliosis. Arch. Public Health, 2021, vol. 79, no. 1, pp. 63. DOI: 10.1186/s13690-021-00584-6

17. Mirskaya N.B., Kolomenskaya A.N., Sinyakina A.D. Prevalence and medical and social importance of disorders and diseases of the musculoskeletal systems in children and adolescents (Review of literature). Gigiena i sanitariya, 2015, vol. 94, no. 1, pp. 97-104 (in Russian).

18. Kostenko Y.Y., Melnyk V.S., Horzov L.F., Potapchuk A.M. Relationship between idiopathic scoliosis of the spine and dentognathic anomalies in adolescents. Wiad. Lek., 2019, vol. 72 (11 cz 1), pp. 2117-2120.

19. Guo Y., Jiang Q., Tanimoto T., Kami M., Luo C., Leppold C., Nishimura K., He Y. [et al.]. Low hospital referral rates of school scoliosis screening positives in an urban district of mainland China. Medicine (Baltimore), 2017, vol. 96, no. 14, pp. e6481. DOI: 10.1097/MD.0000000000006481

20. Baroni M.P, Sanchis G.J., de Assis S.J., dos Santos R.G., Pereira S.A., Sousa K.G., Lopes J.M. Factors associated with scoliosis in schoolchildren: a cross-sectional population-based study. J. Epidemiol., 2015, vol. 25, no. 3, pp. 212-220. DOI: 10.2188/jea.JE20140061

21. Zhang H., Guo C., Tang M., Liu S., Li J., Guo Q., Chen L., Zhu Y., Zhao S. Prevalence of scoliosis among primary and middle school students in Mainland China: a systematic review and metaanalysis. Spine (Phila Pa 1976), 2015, vol. 40, no.1, pp. 41-49. DOI: 10.1097/BRS.0000000000000664

22. Kochetkova E.A., Bubnov O.Y., Vasileva T.G., Geltser B.I. Estimation of calcium-phosphorus exchange in adolescent with carriage disorders. Byulleten' VSNTs SO RAMN, 2006, vol. 47, no. 1, pp. $27-30$ (in Russian).

23. Orlov O.I. Profilaktika narushenii obmena kal'tsiya i sistem ego regulyatsii pri dlitel'noi gipokinezii s uchastiem cheloveka [Prevention of disorders of calcium metabolism and its regulation systems during prolonged hypokinesia with human participation]. Osteoporoz i osteopatii, 2007, vol. 10, no. 3, pp. 21-23. DOI: 10.14341/osteo2007321-23 (in Russian).

24. Mazziotti G., Angeli A., Bilezikian J.P., Canalis E., Giustina A. Glucocorticoid-induced osteoporosis: an update. Trends Endocrinol. Metab., 2006, vol. 17, no. 4, pp. 144-149. DOI: 10.1016/j.tem.2006.03.009

25. Samikulin P.N., Gryaznykh A.V. Changes of cortisol values in young men with different levels of physical fitness during recovery after submaximal muscular load. Chelovek. Sport. Meditsina, 2017, vol. 17, no. 1, pp. 5-13. DOI: 10.14529/hsm170101 (in Russian).

26. Falameeva O.V., Grafov A.V., Kulyaev E.A., Kholodkin V.S., Verkhoturova V.T. Vzaimosvyaz' pokazatelei mineral'noi plotnosti kostnoi tkani s progressirovaniem idiopaticheskogo skolioza u detei i podrostkov [The relationship of bone mineral density indicators with the progression of idiopathic scoliosis in children and adolescents]. V S"ezd khirurgov-vertebrologov Rossii «Vertebrologiya v Rossii: itogi i perspektivy razvitiya»: tezisy doklada na konferentsii. Saratov, El'-Print Publ., 2014, pp. 198-200 (in Russian).

Valina S.L., Shtina I.E., Maklakova O.A., Ustinova O.Yu., Eisfeld D.A. Regularities in diseases of the musculoskeletal system developing in schoolchildren under complex exposure to environmental factors and factors related to lifestyle. Health Risk Analysis, 2021, no. 3, pp. 53-65. DOI: 10.21668/health.risk/2021.3.05.eng

Received: 14.09 .2021

Accepted: 15.09 .2021

Published: 30.09 .2021 